Pesq. Vet. Bras. 37(1):47-51, janeiro 2017

DOI: $10.1590 /$ S0100-736X2017000100008

\title{
Efficacy of oral doramectin as treatment for Psoroptes ovis and Leporacarus gibbus in naturally infested rabbits ${ }^{1}$
}

\author{
Rosângela R. dos Santos², Cristiane N. Coelho², Tiago A.P. Nunes², Lilian \\ Cristina de S.O. Batista ${ }^{2}$, Thaís R. Correia², Fabio B. Scott² ${ }^{2}$ Anaís G.V. \\ Laguna $^{3}$ and Julio I. Fernandes ${ }^{4 *}$
}

\begin{abstract}
Santos R.R., Coelho C.N., Nunes T.A.P., Batista L.C. de S.O., Correia T.R., Scott F.B., Laguna A.G.V. \& Fernandes J.I. 2017. Efficacy of oral doramectin as treatment for Psoroptes ovis and Leporacarus gibbus in naturally infested rabbits. Pesquisa Veterinária Brasileira 37(1):47-51. Laboratório de Quimioterapia Experimental em Parasitologia Veterinária, BR-465 Km 7, Seropédica, RJ 23897-970, Brazil E-mail: vetjulio@yahoo.com.br

The present study evaluated the efficacy of a single oral dose of doramectin in the control of Psoroptes ovis and Leporacarus gibbus in naturally infested rabbits. Sixteen adult rabbits were selected and distributed in two experimental groups. The treated group received $200 \mu \mathrm{g} / \mathrm{Kg}$ of oral doramectin and the control group received the same volume of saline solution. The diagnosis of the mites was made with a stereoscopic microscope. Hairs from the dorsal part of the neck, lumbar right, lumbar left, ventral side of the tail and ventral abdomen were evaluated for L. gibbus, and ear wax evaluated for P. ovis. The evaluation of the efficiency and the clinical assessment of the lesions was made in days $0,+3,+7,+14,+21,+28$, and +35 after treatment. An efficacy of $75 \%$ and $87,5 \%$ was observed for L. gibbus in days +3 and +7 after treatment, an efficacy of $100 \%$ was observed in days $+14,+21,+28$ e +35 . An efficacy of $100 \%$ for the control of $P$. ovis was observed following day +7 . The clinical lesion score of the control group remained unaltered, except for one animal which conditions worsened during experimentation. In the treated group animals, regression of the lesions was observed following day +3 , and on day +21 no signal of infestation by P. ovis was present. None of the animals from the treated group presented secondary collateral effects caused by the doramectin, which proved itself as an optimal alternative for mite control in naturally infested rabbits.
\end{abstract}

INDEX TERMS: Doramectin, Psoroptes ovis, Leporacarus gibbus, macrocyclic lactones, avermectins, Psoroptic mange, rabbits, Oryctolagus cuniculus, mites.

RESUMO.- [Eficácia de doramectin no tratamento oral para Psoroptes ovis e Leporacarus gibbus em coelhos naturalmente infestados.] 0 objetivo do trabalho foi avaliar a eficácia da doramectina administrada por via oral no

\footnotetext{
${ }^{1}$ Received on September on 21, 2015.

Accepted for publication on January 5, 2017.

${ }^{2}$ Laboratório de Quimioterapia Experimental em Parasitologia Veterinária, Departamento de Parasitologia Animal, Universidade Federal Rural do Rio de Janeiro (UFRRJ), Rodovia BR 465, Km 7, Seropédica, RJ 23897970, Brazil

${ }^{3}$ Curso de Pós-Graduação em Medicina Veterinária (CPGMV), UFRRJ, Rodovia BR 465 Km 7, Seropédica, RJ 23890-000, Brazil.

${ }^{4}$ Departamento de Medicina e Cirurgia Veterinária (DMCV), UFRRJ, Rodovia BR $465 \mathrm{Km}$ 7, Seropédica, RJ 23890-000, Brazil. *Corresponding author: vetjulio@yahoo.com.br
}

controle de Psoroptes ovis e Leporacarus gibbus em coelhos naturalmente infestados. Foram selecionados 16 coelhos adultos, distribuídos em dois grupos experimentais, compondo oito animais por grupo. 0 grupo tratado foi medicado com $200 \mu \mathrm{g} / \mathrm{kg}$ de doramectina por via oral, enquanto que no grupo controle foi administrado o mesmo volume de solução salina. 0 diagnóstico dos ácaros foi realizado com auxílio de microscópio estereoscópico. Foram coletados pelos das regiões do pescoço dorsal, lombar direita, lombar esquerda, cauda ventral e abdômen ventral para avaliação de L. gibbus e para $P$. ovis foi coletado cerúmen das orelhas com auxílio de zaragatoas. A avaliação da eficácia e a avaliação clínica das lesões, mensuradas em escores (grau 0 a 4), foi realizada nos dias $0,+3,+7,+14,+21,+28$ e +35 , após o tratamento. Foi observada eficácia de $75 \%$ e $87,5 \%$ no controle 
de L. gibbus nos dias +3 e +7 após o tratamento, sendo observada eficácia de $100 \%$ nos dias $+14,+21,+28$ e +35 . Foi observada eficácia de $100 \%$ no controle de $P$. ovis a partir do dia +7 , permanecendo até o final do período observacional. 0 escore das lesões clínicas no grupo controle permaneceu de forma inalterada, exceto em um animal que piorou ao longo dos dias experimentais, enquanto nos animais do grupo tratado regrediu a partir do dia +3 e já no dia +21 após o tratamento, os animais apresentavam-se sem sinais da infestação por P. ovis. Nenhum animal do grupo tratado apresentou quaisquer efeitos colaterais secundários causados pela doramectina, que se mostrou uma ótima alternativa para o controle dos ácaros em coelhos naturalmente parasitados.

TERMOS DE INDEXAÇÃO: Doramictina, Psoroptes ovis, Leporacarus gibbus, Oryctolagus cuniculus, avermectina, sarna.

\section{INTRODUCTION}

The past decades have brought a change in owners of companion animals, they are now looking for pets that better meet the realities of life in big cities (space, time, cost) and can thrive in them. In this context, the domestic rabbit Oryctolagus cuniculus (Linnaeus, 1758) has stopped being considered an animal solely for food or pelt production, and has become an excellent companion animal, because of their tranquil nature, captivating appearance and easy handling (Hoppmann \& Barron 2007, Melo et al. 2008).

Routinely, these animals are brought to veterinary clinics with a variety of illnesses, dermatologic diseases being responsible for a great part of the cases (Hoppmann \& Barron 2007). Ectoparasites, especially mites like Psoroptes ovis (Hering, 1838) and Leporacarus gibbus (Pagenstecher, 1861) (White et al. 2002), are the most frequent cause of these dermatoses.

L. gibbus is commonly found in laboratory rabbits, but can also be found in small breederies. Infestations can be sub diagnosed, because the mite can escape tests with adhesive tape. Small infestations in healthy rabbits are normally asymptomatic, however heavy infestations can cause alopecia, acute moist pyotraumatic dermatitis and pruritus (Serra-Freire et al. 2010). Subclinical infestations can be related to immunosuppression, aging process and concomitant diseases (Lennox \& Kelleher 2009, D’Ovidio \& Santoro 2014).

$P$. ovis can infest a diverse number of mammalian species, including rabbits. It is the most frequently reported ectoparasite in this species (Wall \& Kolbe 2006). The clinical manifestation in infested rabbits is bilateral otitis, with an intense crust formation that can eventually affect the whole pinnae, in addition to pruritus and ulcers (Cutler 1998, Chen et al. 2000), predisposing to the appearance of secondary bacterial infections (Morrisey 1996). In more severe cases, the infestation can lead way to otitis media, tympanic membrane perforation and neurological signs (White et al. 2002).

Different drugs have been used for the treatment of these ectoparasites with good results, such as ivermectin (Pandey 1989, Stephen et al. 1990, Coelho et al. 2014), moxidectin (Wagner \&Wendlberger 2000), eprinomectin (Pan et al. 2006), selamectin (McTier et al. 2003, Fisher et al. 2007), permethrins (Melo et al. 2008), d-phenothrin/pyripro- xyfen associations (Fernandes et al. 2013), pyriprole (Batista et al. 2013), and phytotherapeutic products (Maske \& Kolte 1999, Joshi et al. 2000, Fernandes et al. 2012, Nong et al. 2012), administered topically or systemically.

Doramectin, a genetically modified avermectin, possesses a plasma half-life and acting period greater than that of ivermectin (Voyvoda et al. 2005). It is a molecule with endo and ectoparasitic activity, with an ample specter and used in many species of animals. Even though the use of doramectin in rabbits is "off label", its use in this species has grown in the past years. Rabbits have been shown to absorb and eliminate it quicker, when compared to bovines and ovines (Li et al. 2009).

Subcutaneously and intramuscularly applied doramectin in rabbits, in different doses, was used for the control of Psoroptes sp. with good results (Narayanan et al. 2004, Kanbur et al. 2008), nonetheless there are no reports of its usage orally.

The aim of the present study was to evaluate the efficacy of a single $200 \mu \mathrm{g} / \mathrm{kg}$ oral dose of doramectin in the control of $P$. ovis and L. gibbus in naturally infested rabbits, seeing as this is a more practical route of administration to be performed by the owners of sick animals.

\section{MATERIALS AND METHODS}

Ethics statement. The experiment was performed in the dependencies of the Laboratório de Quimioterapia Experimental em Parasitologia Veterinária (LQEPV), belonging to the Department of Parasitology (DPA) of the Veterinary Institute (IV) of the Universidade Federal Rural do Rio de Janeiro (UFRRJ), located in the municipality of Seropédica, state of Rio de Janeiro. It was approved by the ethics committee (Comitê de Ética de Uso de Animal - CEUA) of the same university, with protocol number 120/2014.

Animals and study design. Sixteen healthy rabbits of a California and New Zeland cross breed, with an estimated age of 1 year; weighing between 3,0 and 3,5 kg; from a small breeder in the region of Seropédica, Rio de Janeiro) naturally co-infested with $P$. ovis and L. gibbus were selected and divided into two groups. The groups contained male and female individuals in a proportional number, control and treated, with eight animals each, in individual suspended cages. The treated group received a single dose of $200 \mu \mathrm{g} / \mathrm{Kg}$ oral doracmectin (Dectomax ${ }^{\circledR} 1 \%$ injectable solution) (Narayanan et al. 2004, Kanbur et al. 2008), whilst the control group received the same volume of saline solution.

The presence of $P$. ovis was diagnosed utilizing a stereoscopic microscope, by observing mites in samples of ear wax and crusts collected with cotton swabs. The lesion score and criteria utilized during the evaluation was as follows: 0 for apparently normal ears; 1 for lesions inside the ear; 2 for lesion on the bottom third $(1 / 3)$ of the ear; 3 for lesions that extended two thirds $(2 / 3)$ of the ear and 4 for lesions with a greater extension than two thirds of the ear (Pan et al. 2006).

For the diagnosis of Leporacarus gibbus, $1 \mathrm{~cm}$ of hair was collected from each one of these regions: dorsal part of the neck, lumbar right, lumbar left, ventral side of the tail and ventral abdomen. A positive diagnosis, as well as mite motility, was evaluated with a stereoscopic microscope (Birke et al. 2009).

The lesion score and presence of mites was evaluated on day 0 (pre-treatment) and days, $+3,+7,+14,+21,+28$ and +35 post-treatment. The efficacy was calculated with an adapted version of the formula proposed by Marchiondo et al. (2013): ((number of infested animals with live mites before treatment - number of 
infested animals with live mites after treatment)/(number of infested animals with live mites before treatment)) x 100 .

All animals were clinically examined daily until the end of the observation period, because of possible adverse reactions triggered by the use of doramectin. At the end of the experiment the animals that were in the control group were also treated with doramectin, in the same dose and method as explained above.

Statistics. The statistical analysis was done by comparing the number of positive animals present for each group and for each species of parasite, using the Fisher Exact Test. The lesion scores from the ears of each animal were evaluated using the Mann Whitney non parametric test, were the mean score of both ears of the animals in the control and treated group. A significance level of $95 \%(\mathrm{p} \leq 0,05)$ was used. The statistical program used was BioEstat 5.3 (Ayres et al. 2007).

\section{RESULTS}

Rabbits belonging to the control group remained infested by Psoroptes ovis and Leporacarus gibbus throughout the entire experimental period, they received the same treatment as the other group when the study was completed. The results of the evaluations corresponding to the presence of mites in the control group and the group treated with oral doramectin for the control of de P. ovis and L. gibbus can be found on Table 1.

On day +3 , five rabbits remained infested with $P$. ovis and two of them with L. gibbus, attaining an efficacy of $37,5 \%$ and $75 \%$, respectively. No live $P$. ovis mites were observed following day +7 , maintaining a $100 \%$ efficacy until the end of the observational period (day +35). For L. gibbus, the efficacy was $100 \%$ following day +14 . In the previous evaluation (+7) one animal remained infested. There was a significant difference between the control group and the treated group starting the day +3 L. gibbus $(\mathrm{p}=0.007)$ and day 7 for $P$. ovis $(\mathrm{p}=0.0014)$.

The clinical evaluation of otitis in the animals infested with $P$. ovis is described on Table 2 . On day 0 , all animals in both groups presented lesions characteristic of the presence of $P$. ovis, such as erythema, crusts and pruritus.

Animals belonging to the control group maintained the same score throughout the experimental days, excluding one rabbit, which score changed from 3 to 4 on day +14 . Lesions present on the control group at the end of the experimental period can be observed. Of the eight animals belonging to the treated group, just two animals did not have a clinical improvement by day +3 . By day +14 , only one animal remained with lesions, not achieving a clinical improvement. However, from day 7 a possible significant difference between the groups was observed $(p=0.0181)$. From day +21 , none of the animals presented anymore ear canal lesions. No adverse reactions to the single dose of $200 \mu \mathrm{g} / \mathrm{kg}$ of oral doramectin were observed in any rabbit.

\section{DISCUSSION}

Although intoxications in rabbits using doramectin have been described as presenting with convulsions, diarrhea, tremors, lethargy, mydriasis and blindness (Voyvoda et al. 2005), none of the animals treated showed adverse reactions. In the same paper, an inflammatory reaction and pain at the application site in rabbits treated with $400 \mu \mathrm{m}$ of injectable doramectin was described, however, one of the advantages of using the product orally is the absence of this important collateral effect.

As observed by Pan et al. (2006), there have been few studies involving the development of Psoroptes ovis in rabbits. In the same study that tested eprinomectin in rabbits, the authors observed that the mite population in the control group tripled during the experimental period (day +35 ). In the present study, individual mite counts were not performed, however the evolution of the lesion followed a slower pace, with only one rabbit changing the lesion score.

The efficacy of doramectin was similar to that reported by other authors using different chemical groups, like pyre-

Table 1. Presence of Psoroptes ovis and Leporacarus gibbus in rabbits belonging to the control and treated with oral doramectin groups, before and after treatment

\begin{tabular}{|c|c|c|c|c|c|c|c|c|c|c|c|c|c|c|}
\hline \multirow{3}{*}{$\begin{array}{l}\text { Groups/ } \\
\text { Animals }\end{array}$} & \multicolumn{14}{|c|}{ Presence of Psoroptes ovis and Leporacarus gibbus in rabbits pre and post treatment } \\
\hline & \multicolumn{2}{|c|}{ Day 0} & \multicolumn{2}{|c|}{ Day +3} & \multicolumn{2}{|c|}{ Day +7} & \multicolumn{2}{|c|}{ Day +14} & \multicolumn{2}{|c|}{ Day +21} & \multicolumn{2}{|c|}{ Day +28} & \multicolumn{2}{|c|}{ Day +35} \\
\hline & P. ovis & L. gibbus & P. ovis & L. gibbus & P. ovis & L. gibbus & P. ovis & L. gibbus & P. ovis & L. gibbus & P. ovis & L. gibbus & P. ovis & L. gibbus \\
\hline \multicolumn{15}{|l|}{ Control } \\
\hline 1 & + & + & + & + & + & + & + & + & + & + & + & + & + & + \\
\hline 2 & + & + & + & + & + & + & + & + & + & + & + & + & + & + \\
\hline 3 & + & + & + & + & + & + & + & + & + & + & + & + & + & + \\
\hline 4 & + & + & + & + & + & + & + & + & + & + & + & + & + & + \\
\hline 5 & + & + & + & + & + & + & + & + & + & + & + & + & + & + \\
\hline 6 & + & + & + & + & + & + & + & + & + & + & + & + & + & + \\
\hline 7 & + & + & + & + & + & + & + & + & + & + & + & + & + & + \\
\hline 8 & + & + & + & + & + & + & + & + & + & + & + & + & + & + \\
\hline \multicolumn{15}{|l|}{ Treated } \\
\hline 1 & + & + & + & - & - & - & - & - & - & - & - & - & - & - \\
\hline 2 & + & + & + & - & - & + & - & - & - & - & - & - & - & - \\
\hline 3 & + & + & - & - & - & - & - & - & - & - & - & - & - & - \\
\hline 4 & + & + & + & + & - & - & - & - & - & - & - & - & - & - \\
\hline 5 & + & + & - & - & - & - & - & - & - & - & - & - & - & - \\
\hline 6 & + & + & - & - & - & - & - & - & - & - & - & - & - & - \\
\hline 7 & + & + & + & - & - & - & - & - & - & - & - & - & - & - \\
\hline 8 & + & + & + & + & - & - & - & - & - & - & - & - & - & - \\
\hline P Value & 1.00 & 1.00 & 0.200 & 0.007 & 0.0002 & 0.0014 & 0.002 & 0.0002 & 0.002 & 0.0002 & 0.0002 & 0.0002 & 0.0002 & 0.0002 \\
\hline Efficacy & & & $37.5 \%$ & $75 \%$ & $100 \%$ & $87.5 \%$ & $100 \%$ & $100 \%$ & $100 \%$ & $100 \%$ & $100 \%$ & $100 \%$ & $100 \%$ & $100 \%$ \\
\hline
\end{tabular}


Table 2. Scores for the lesions caused by Psoroptes ovis in rabbits belonging to the control and treated with oral doramectin groups, before and after treatment

\begin{tabular}{|c|c|c|c|c|c|c|c|c|c|c|c|c|c|c|}
\hline \multirow{3}{*}{$\begin{array}{l}\text { Groups/ } \\
\text { Animals }\end{array}$} & \multicolumn{14}{|c|}{ Extent of ear canal lesion caused by Psoroptes ovis before and after treatment. } \\
\hline & \multicolumn{2}{|c|}{ Day 0} & \multicolumn{2}{|c|}{ Day +3} & \multicolumn{2}{|c|}{ Day +7} & \multicolumn{2}{|c|}{ Day + 14} & \multicolumn{2}{|c|}{ Day +21} & \multicolumn{2}{|c|}{ Day +28} & \multicolumn{2}{|c|}{ Day +35} \\
\hline & LE & $\mathrm{RE}$ & LE & $\mathrm{RE}$ & LE & $\mathrm{RE}$ & LE & $\mathrm{RE}$ & LE & RE & LE & $\mathrm{RE}$ & LE & $\mathrm{RE}$ \\
\hline \multicolumn{15}{|l|}{ Control } \\
\hline 1 & 2 & 2 & 2 & 2 & 2 & 2 & 2 & 2 & 2 & 2 & 2 & 2 & 2 & 2 \\
\hline 2 & 2 & 2 & 2 & 2 & 2 & 2 & 2 & 2 & 2 & 2 & 2 & 2 & 2 & 2 \\
\hline 3 & 3 & 3 & 3 & 3 & 3 & 3 & 3 & 3 & 3 & 3 & 3 & 3 & 3 & 3 \\
\hline 4 & 1 & 1 & 1 & 1 & 1 & 1 & 1 & 1 & 1 & 1 & 1 & 1 & 1 & 1 \\
\hline 5 & 4 & 4 & 4 & 4 & 4 & 4 & 4 & 4 & 4 & 4 & 4 & 4 & 4 & 4 \\
\hline 6 & 3 & 3 & 3 & 3 & 3 & 3 & 4 & 4 & 4 & 4 & 4 & 4 & 4 & 4 \\
\hline 7 & 2 & 2 & 2 & 2 & 2 & 2 & 2 & 2 & 2 & 2 & 2 & 2 & 2 & 2 \\
\hline 8 & 2 & 2 & 2 & 2 & 2 & 2 & 2 & 2 & 2 & 2 & 2 & 2 & 2 & 2 \\
\hline \multicolumn{15}{|l|}{ Treated } \\
\hline 1 & 2 & 2 & 1 & 1 & 1 & 1 & 0 & 0 & 0 & 0 & 0 & 0 & 0 & 0 \\
\hline 2 & 2 & 2 & 1 & 1 & 1 & 1 & 0 & 0 & 0 & 0 & 0 & 0 & 0 & 0 \\
\hline 3 & 2 & 2 & 1 & 1 & 1 & 1 & 0 & 0 & 0 & 0 & 0 & 0 & 0 & 0 \\
\hline 4 & 2 & 2 & 1 & 1 & 1 & 1 & 0 & 0 & 0 & 0 & 0 & 0 & 0 & 0 \\
\hline 5 & 3 & 3 & 1 & 1 & 1 & 1 & 0 & 0 & 0 & 0 & 0 & 0 & 0 & 0 \\
\hline 6 & 4 & 4 & 1 & 1 & 1 & 1 & 0 & 0 & 0 & 0 & 0 & 0 & 0 & 0 \\
\hline 7 & 2 & 2 & 2 & 2 & 1 & 1 & 0 & 0 & 0 & 0 & 0 & 0 & 0 & 0 \\
\hline 8 & 4 & 4 & 4 & 4 & 3 & 3 & 2 & 2 & 0 & 0 & 0 & 0 & 0 & 0 \\
\hline P Value & \multicolumn{2}{|c|}{0.6744} & \multicolumn{2}{|c|}{0.6744} & \multicolumn{2}{|c|}{0.0181} & \multicolumn{2}{|c|}{0.0023} & \multicolumn{2}{|c|}{0.0008} & \multicolumn{2}{|c|}{0.0008} & \multicolumn{2}{|c|}{0.0008} \\
\hline
\end{tabular}

throids (Melo et al. 2008, Fernandes et al. 2013), phenylpyrazoles (Batista et al. 2013) and other avermectins (Pan et al. 2006). Doramectin presented a greater action period when compared to ivermectin (Voyvoda et al. 2005), nonetheless the results of its usage do not differ from other reports.

Coelho et al. (2014) performed a 35 day study evaluating the efficacy of oral ivermectin in the control of Psoroptes ovis and Leporacarus gibbus in naturally infested rabbits. The authors reported $100 \%$ for $P$. ovis in days $+7,+21$, +28 and +35 , with only one positive rabbit on day +14 ; and $100 \%$ efficacy for L. gibbus following day +14 . These results are similar to the ones found by this study, where $100 \%$ efficacy for $P$. ovis can be found following day +7 , and $100 \%$ for L. gibbus can be found following day +14 . Furthermore, in both studies the remission of ear lesions caused by P. ovis occurred following day +21 in $100 \%$ post treatment.

Birke et al. (2009) reported the efficacy of selamectin and the association of permethrin and imidacloprid for the treatment of L. gibbus in laboratory rabbits, with both formulations presenting $100 \%$ efficacy on day +13 , similar to this study where $100 \%$ efficacy was obtained on day +14 post treatment. The authors reported that selamectin, an avermectin from the same group as doramectin, was the best option, seeing as the rabbits were mite free from day +3 . In the present study, a 100\% efficacy for the control of L. gibbus was only observed after day +14 .

Narayanan et al. (2004) observed that ear lesions caused by $P$. ovis in rabbits regressed following day +14 post treatment; this fact was also observed in the present study. Nevertheless, one animal only obtained clinical cure after day +21 , this fact could be related to the severity of the lesions at the beginning of the experiment. Another important factor to be reported is the route of administration for the medications. While Narayanan et al. (2004) medicated the rabbits subcutaneously, this study used an oral administration, and the results were similar.
The route of administration does not seem to alter the efficacy of doramectin for the control of mites. The rabbit is no longer just a production animal and is now considered a pet. For their guardians, administration of a drug by oral route is less traumatic and consequently better, in terms of animal welfare, when compared to the stress resulting from the restraint and application of a product used subcutaneously or intramuscularly.

Kanbur et al. (2008) reported that doramectin has a $100 \%$ efficacy for the treatment of Psoroptes sp. infested rabbits, with a $200 \mu \mathrm{g} / \mathrm{kg}$ intramuscular dose, these results are similar with the ones attained by Narayanan et al. (2004) utilizing a subcutaneous route and this present study utilizing an oral route. However, since rabbits are being breeded as companion animals, one should note that the oral route has more practicality when compared to the other routes.

\section{CONCLUSION}

A single dose of $200 \mu \mathrm{g} / \mathrm{kg}$ doramectin given orally was efficient in the control of Psoroptes ovis and Leporacarus gibbus in naturally infested rabbits.

Acknowledgements.- The authors thank the National Council for Scientific and Technological Development (CNPq) of Brazil and Coordination of Improvement of Higher Education Personnel (CAPES)funds.

Conflict of interest statement.- The authors have no competing interests.

\section{REFERENCES}

Ayres M., Ayres Júnior M., Ayres D.L. \& Santos A.D.A. 2007. Aplicações Estatísticas nas Áreas das Ciências Bio-Médicas. Instituto Mamirauá, Belém. $364 \mathrm{p}$

Batista L.C.S.O., Coelho C.N., Nunes T.A.P., Lambert M.M., Fernandes J.I., Correia T.R., Scott F.B. \& Coumendouros K. 2013. Eficácia do piriprol no controle de Psoroptes ovis e Leporacarus gibbus em coelhos naturalmente co-infestados. Revta Bras. Med. Vet. 35(2):126-130. 
Birke L.L., Molina P.E., Baker D.G., Leonard S.T., Marrero L.J., Johnson M. \& Simkin J. 2009. Comparison of selamectin and imidacloprid plus permethrin in eliminating Leporacarus gibbus infestation in laboratory rabbits (Oryctolagus cuniculus). J. Am. Assoc. Lab. Anim. Sci. 48(6):757-762.

Chen L.P., Chung T.K. \& Lin S.C. 2000. Psoroptes cuniculi infestation in rabbits in central Taiwan. J. Chin. Soc. Vet. Sci. 26(4):284-292.

Coelho C.N., Nunes T.A.P., Batista L.C.S.O., Silva D.D., Santos R.R., Correia T.R., Scott F.B. \& Fernandes J.I. 2014. Eficácia da ivermectina oral no controle de Psoroptes ovis e Leporacarus gibbus em coelhos naturalmente infestados. Pesq. Vet. Bras. 34(9):832-836.

Cutler S.L. 1998. Ectopic Psoroptes cuniculi infestation in a pet rabbit. J. Small. Anim. Pract. 39(2):86-87.

D'Ovidio D. \& Santoro D. 2014. Leporacarus gibbus infestation in client-owned rabbitsand their owner. Vet. Dermatol. 25:46-e17.

Fernandes J.I., Verocai G.G., Ribeiro F.A., Melo R.M.P.S., Correia T.R., Veiga C.C.P., Vieira V.P.C. \& Scott F.B. 2012. Eficácia acaricida de uma emulsão contendo $10 \%$ de óleo de nim (Azadirachta indica) no controle de Psoroptes ovis em coelhos naturalmente infestados. Pesq. Vet. Bras. 32(12):1253-1256.

Fernandes J.I., Verocai G.G., Ribeiro F.A., Melo R.M.P.S., Correia T.R., Coumendouros K. \& Scott F.B. 2013. Efficacy of the d-phenothrin/pyriproxyfen association against mites in naturally co-infested rabbits. Pesq. Vet. Bras. 33(5):597-600.

Fisher M., Beck W. \& Hutchinson M.J. 2007. Efficacy and Safety of Selamectin (Stronghold ${ }^{\circledR} /$ Revolution $^{\mathrm{TM}}$ ) Used Off-Label in Exotic Pets. Int. J. Appl. Res. Vet. Med. 5(3):87-96.

Hoppmann E. \& Barron H.W. 2007. Rodent dermatology. J. Exo. Pet. Med. 16(4):238-255.

Joshi S.S., Dakshinkar N.P., Sapre V.A. \& Sarode D.B. 2000. Evaluation of herbal medicaments in psoroptic mange of rabbits. Indian Vet. J. 77(8): 706-708.

Kanbur M., Atalay O., Ica A., Eraslan G. \& Cam Y. 2008. The curative and antioxidative efficiency of doramectin and doramectin + vitamin AD3E treatment on Psoroptes cuniculi infestation in rabbits. Res. Vet. Sci. 85:291-293.

Lennox A.M. \& Kelleher S. 2009. Bacterial and parasitic diseases of rabbits. Vet. Clin. North. Am. Exot. Anim. Pract. 12(3):519-530.

Li N., Jiang H., Li J., Wang Z., Li C., Li X. \& Ding S. 2009. Pharmacokinetics of doramectin in rabbits after subcutaneous administration. J. Vet. Pharmacol. Therap. 32:397-399.

Marchiondo A.A., Holdsworth P.A., Fourie L.J., Rugg D., Hellmann K., Snyder D.E. \& Dryden M.W. 2013. World Association for the Advancement of Veterinary Parasitology (W.A.A.V.P.) second edition: guidelines for evaluating the efficacy of parasiticides for the treatment, prevention and control of flea and tick infestations on dogs and cats. Vet. Parasitol. 194(1):84-97.

Maske D.K. \& Kolte S.W. 1999. Studies on life-cycle of psoroptic mange mite in rabbits and chemotherapy under experimental conditions. Vet. Parasitol. 13(1):45-47.

McTier T.L., Hair J.A., Walstrom D. \& Thompson L. 2003. Efficacy and safety of topical administration of selamectin for treatment of ear mite infestation in rabbits. J. Am. Vet. Med. Assoc. 223(3):322-324.

Melo R.M.P.S., Fernandes J.I., Vieira V.P.C., Ribeiro F.A., Botelho M.C.S.N., Verocai G.G. \& Scott F.B. 2008. Eficácia do piretróide permetrina no controle de Psoroptes ovis (Hering, 1838) (Acari: Psoroptidae) em coelhos (Oryctolagus cuniculus) naturalmente infestados. Revta Bras. Parasitol. Vet. 17:55-58.

Morrisey J.K. 1996. Parasites of Ferrets, rabbits and rodents. Semin. Avian Exot. Pet Med. 5(2):106-114.

Narayanan K., Rajendiran A.S. \& Rajapandi S. 2004. Effect of doramectin on the treatment of ear and skin mange in rabbits. Indian Vet. J. 81:628630.

Nong X., Fang C.L., Wang J.H., Gu X.B., Yang D.Y., Liu T.F., Fu Y., Zhang R.H., Zheng W.P., Peng X.R., Wang S.X. \& Yang G.Y. 2012. Acaricidal activity of extract from Eupatorium adenophorum against the Psoroptes cuniculi and Sarcoptes scabiei in vitro. Vet. Parasitol. 187(1/2):345-349.

Pan B., Wang M., Xu F., Wang Y., Dong Y. \& Pan Z. 2006. Efficacy of an injectable formulation of eprinomectina against Psoroptescuniculi, the ear mange mite in rabbits. Vet Parasitol. 137(3/4):386-390.

Pandey V.S. 1989. Effect of ivermectin on the ear mange mite, Psoroptes cuniculi, of rabbits. Brit. Vet. J. 145(1):54-56.

Serra-Freire N.M., Benigno R.N.M. \& Falcão K. 2010. Casos clínicos de dermatite por Leporacarusgibbus (Acari: Listrophoridae) em criações zootécnicasde coelhos domésticos (Oryctolaguscuniculus) nos estados do Pará e São Paulo. Revta Bras. Med. Vet. 32(2):111-114.

Stephen K.C., Regina H. \& Dale L.B. 1990. Use of ivermectina for treatment of ear mite infestation in rabbits. J. Am. Vet. Med. Assoc. 196:1139-1140.

Voyvoda H., Ulutas B., Eren H., Karagenc T. \& Bayramli G. 2005. Use of doramectin for treatment of sarcopitic mange in five Angora rabbits. Vet. Dermatol. 16(4):285-288.

Wall R.K. \& Kolbe K. 2006. Taxonomic priority in psoroptic mange mites: $P$. ovis or P. equi? Exp. Appl. Acarol. 39(2):159-162.

Wagner R. \& Wendlberger U. 2000. Field efficacy of moxidectin in dogs and rabbits naturally infested with Sarcoptes spp., Demodex spp. and Psoroptes spp. mites. Vet. Parasitol. 93(2):149-158.

White S.D., Bourdeau P.J. \& Meredith A. 2002. Dermatologic problems of rabbits. Semin. Avian Exot. Pets 11(3):141-150. 